\title{
A FLYING EROS FROM THE SCHOOL OF PRAXITELES.
}

\author{
[Plate VIII.]
}

THe terracotta reproduced on Plate VIII. with the kind permission of Mr. A. S. Murray was acquired by the British Museum in the course of this year from Eretria, where it was found in a tomb. It measures together with the wings $1 \mathrm{ft} .9 \frac{5}{8} \mathrm{in}$. in height, and is composed of a greyish, fine-grained, well baked clay, which, as may be seen on the broken fingers of the left hand, shows a purplish tint when fractured. ${ }^{I}$

It is in perfect preservation, and the wings form an organic whole with the body. The delicacy of the modelling is especially conspicuous on the head and wings; at the same time it has suffered from a yellowish incrustation of some thickness. The whole statuette was covered in the first place with a lustrous white engobe; in addition the hair was painted red-brown, the wings green on the front side, the chlamys rose-colour, and the sandals purple; further, the tongue (lunula) of the sandals is yellow, or rather gilt. At the back the wings are neither worked nor painted; between them appears a small quadrilateral opening. This fact justifies the supposition that the Eretrian terracottas were destined for hanging against the wall, so as to have from a distance the appearance of objects in relief.

The figure is that of an ephebos of slender proportions, but the character of Eros is adequately indicated by the large wings. ${ }^{2}$ The action of the

\footnotetext{
${ }^{1}$ It is interesting to put on record that the clay of our terracotta corresponds closely to the ashen-grey earth of Eretria described by

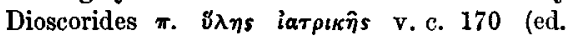
Sprengel) : Tî̀ 'E

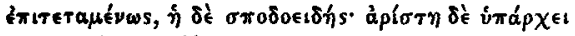

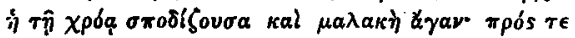

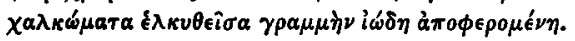
Also Pliny, Hist. Nat. xxxv. 54 : 'Namque et alba est et cinerea, quae praefertur in medicina. Probatur mollitie : et quod si aere perducatur, violaceum reddit colorem.' In view of this, it may be apposite to raise the question whether there was in Eretria in the fourth century a manufacture of terracottas dependent on those of Attica and Tanagra, yet distinct from them, such as has been already assumed for the fifth
}

H.S. - VOL, XY. century lekythi (cf. Staes in 'E $\phi \eta \mu$. 'A $\rho \chi .1894$, p. 65). In the National Museum at $A$ thens are some fifty terracottas from Eretria, all without exception from the excavations of the last seven years. With the exception of a vase in the form of a negro's head (published by Hartwig

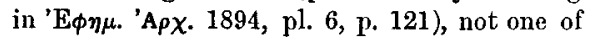
them has as yet been made known, although some may rank as masterpieces. None are over one foot high, and compared with them our terra. cotta ranks very high. See $\Delta \in \lambda \tau i$ iov, 1889, pp. $74,115,171$; and compare also a terracotta published by Miss Hutton in the current volume of this journal, pl. 4, fig. 2, p. 134.

2 On Eros and his sepulchral signification see Furtwaengler in Roscher's Mythol. Lexicon, art. Eros; Collignon in Dictionn. des Antiq. art. 


\section{A FLYING EROS FROM THE SCHOOL OF PRAXITELES.}

left wrist implies that he has held some very light object, probably a wreath or a taenia. The whole composition suggests Praxiteles, and the stylistic details confirm this first impression. The head vividly recalls the Hermes at Olympia, and the Aberdeen head in the British Museum; ${ }^{3}$ but it is above all in the angle of the head, the form of the cranium and neck, and the shape of the nose and forehead that the similarity to the latter example is so conspicuous. At the back of the head are obvious signs of a wreath or fillet, which now no longer exists. The wonderful wings can only be compared with the genuine wings of the Palatine Eros, and the Borghese Eros in the Louvre; they are formed of several rows of short fan-like feathers and long sword-like pinions. The form of the hips, rather thick than broad, is another link with the Borghese statue. The manner in which the chlamys is drawn diagonally over the breast from the right shoulder, while at the same time allowing the body to be seen through, finds its closest analogy in the works of Praxiteles, e.g. the Bacchus of Versailles in the Louvre, which Furtwaengler (Masterpieces, p. 337) has ascribed to the master himself. Only one other Eros statue of Praxitelean style wears so long a chlamys as that of our example; a copy of this is seen in a Pompeian wall-painting published by Zahn, Ornamente u. Gemälde aus Pompei, i. 99.4

In other aspects our terracotta presents certain differences which show that the artist was acquainted, not only with the works of Praxiteles, but perhaps also with the Belvedere Hermes, the supposed work of the sons of Praxiteles about 330 B.c. (see my article in Revue Archéol. June, 1895). The Eretrian Eros has all the rhythm of movement and harmony of the lastnamed. The face again is not sweetly smiling, but serious and reflective, as is that of the Hermes, which had been erected over a grave. In both cases the head turns to that side on which the hips bend outwards, while this bend is as strongly marked, and the right knee-cap as firmly rendered, as in the

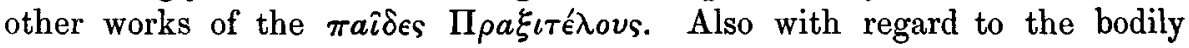
proportions, our statuette, although representing a slightly younger ephebos,

Cupido; Pottier and S. Reinach, Nécropole de Myrina, index s.v. Eros, and especially p. 329 ; Benndorf, Bullet. municip. 1886, p. $70 \mathrm{ff}$.

3 Published by Miss E. Sellers in Eurtwaen. gler's Masterpieces, pl. 18.

4 This Eros in position and action of the arms corresponds minutely with the Dresden Artemis, which Furtwaengler (Masterpicces, p. 324, fig. 139) regards as a product of the older period of Praxiteles. The head is gently inclined to balance the rigid left leg, and the bow is held in his left hand, while with the right he draws up his chlamys behind the shoulder just as the Diana of Gabii, which Studniczka (Vermuth. zu gr. Kunstgesch. p. 18ff.) has identified with the Artemis Brauronia of Praxiteles. The type of countenance connects it with the Eros of Centocelle, as also do the long curls of hair, the relatively short wings, and the similarity of the whole conception (for instance, he makes no use of his weapons, but bends his head in reflection). Besides the three well-known examples we can point to a fourth Eros from the hand of Praxiteles, namely, that which Verres stole from the house of Mamertinus Heius at Messana, where it had been preserved for many generations. Cicero, in Verrem, iv. 24, calls it similar to the Eros of Thespiae: 'idem prius artifex (= Praxiteles) eiusdem modi Cupidinem fecit illum qui est in Thespiis, propter quem Thespiae visuntur, nam alia visendi nulla causa est.' If then the Centocelle statue represents the Thespian Eros, the fourth and similar Eros-type may be preserved to us in the above-mentioned Pompeian statue. In this case it would be an older work of Praxiteles, and as it were introductory to his later Thespian masterpiece. 
and on a smaller scale, approaches most nearly to the Belvedere Hermes. There is the same individual roundness and breadth of composition in the upper part of the body with its prominent breast and relatively small head. There are as yet no signs of an immediate Lysippian influence, still less of the proportions of the flying Erotes from Megara and Myrina (Pottier and S. Reinach, Nécropole de $M$. pls. 11-14, p. 328), which on account of their sepulchral use afford the closest parallel with our terracotta.

The deviations of the Eretrian Eros from the Belvedere Hermes-type are explained by the fact that the former was intended to be hovering in the air. In order to express the backward and forward movement, the leg is much advanced, the toes drawn back under the foot. To avoid any appearance of excessive heaviness in the lower part of the body the arms are pressed close to the chest in Polycleitan fashion, and serve as a point of support for the mantle, the pendent folds of which present the appearance of a second pair of wings. This deviation from the Praxitelean pattern is not very happily executed; the two fore-arms are the only parts of the body of which the drawing and modelling leave anything to be desired.

We have seen then that the Eretrian terracotta is very closely connected with the Hermes of Olympia and the Belvedere Hermes. Like the latter, it may be regarded as the production of an artist working between B.c. 340 and B.c. 330, in full accordance with the artistic traditions of Praxiteles.

This influence-a natural result of the close political relations between Athens and Eretria ${ }^{5}$-is further represented from the latter city by two works of art: the female head discussed by Furtwaengler, Samml. Sabouroff, pls. 12-14, and the statue of a youth in the store-rooms of the National Museum at Athens, the head of which appears to have been inspired by the Hermes of Olympia. ${ }^{6}$ The influence of Praxitelean art on ceramics generally, and especially on the Tanagra terracottas, has been frequently touched upon, the latest discussion being by M. Mayer, Athen. Mittheil. 1892, p. $261 \mathrm{ff}$., who collects all the older literature; but in this sphere there yet remains very much to be done. ${ }^{7}$

Eros in the form of a winged Hermes is not hitherto known, although the development of art, and the close relation of Eros to Hermes, naturally tend in that direction. Apart from attributes and the slight distinction of age, the sculpture of the fourth century recognized a difference between the ephebos Eros and the ephebos Hermes, whether through the more or less girlish treatment of the hair or the rounded boyish face. Even on the two monuments $^{8}$ where the bodily proportions of Eros are stronger than

\footnotetext{
5 For the history of Eretria, see Richardson in American Journ. of Archaeol. 1891, p. $234 \mathrm{ff}$.

II know it only from $S$. Reinach's Chroniques d'Oricnt, p. 336 ; in 1892 it was not exhibited, and it is not described in Kavvadias' $\Gamma \lambda v \pi \tau \dot{a}$

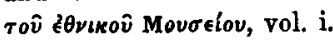

3 On the influence of Lysippian art on the Smyrna terracottas, see Reinach, Melanges
}

Graux, p. $156 \mathrm{ff}$; also Necropole de Myrina, p. 159 .

8 The seulptured column from Ephesos (J.H.S. xi. p. 280) and a terracotta of unknown provenience (Lecuyer, $2^{\text {me }}$ collection, pl. 13). The terracotta, if genuine, must be connected with the Ludovisi Ares. 


\section{A FLYING EROS FROM THE SCHOOL OF PRAXITELES.}

elsewhere, the smoothly divided hair in the first place and the rounded, roguish face in the second, serve to differentiate him from Hermes. Eros with close-shorn curly hair and severe athletic face is in the fifth century a very rare, ${ }^{9}$ in the fourth a hitherto quite isolated phenomenon. The closest analogy to the Eretrian Eros is the athlete on a Campana relief (Campana, Opere in plastica, 94), preserved in many other reproductions; in his left hand is a palm, and with the right he places a wreath on his own head. Milchhöfer (Archäol. Studien H. Brunn dargebr. p. 62 ff.) has rightly traced it back to the picture by Eupompos (Pliny, $H . N$. xxxv. 75). The same figure, but somewhat more youthful, with the same motive, appears as an Eros with large wings on a later tetradrachm published by E. Beulé (Les monnaies d'Athenes, p. 222). The Eretrian terracotta in a mythological aspect may be regarded as the oldest certain example of that fusion of religious ideas which in the epoch of the Tanagra and Myrina terracottas gave rise on the one hand to bizarre creations, on the other to conceptions full of charm.

Nevertheless it must be acknowledged that the artist of our terracotta, if wanting in originality, has yet produced a perfectly complete and successful composition, the rhythm of which has an especial charm. As regards the seriousness of the conception we can only compare the Eros with a lyre on a lekythos of the 'strong fine' period published by Benndorf (Gr. u. Sic. Vasenbilder, pl. 48, fig. 2), or the Eros head of Pheidian period published by Furtwaengler, Meisterw. Figs. 12-13. But while the movement of the latter still shows signs of awkwardness, in this case the problem is undoubtedly solved with entire success, thanks to the influence of painted sculpture, though almost without realism. Upward flight is expressed by the same means, and quite as harmoniously, on a contemporaneous work of art, the Ganymede of Leochares, whose prototype Furtwaengler has recognized in an older pictorial composition (Samml. Sabouroff; text to pl. 147, p. 5). On vases too, the lightly-hovering Erotes first appear rendered correctly in the fourth century; in the fifth they usually float diagonally down with stiff extended legs or bent-in knees and upward-curving bodies, unaffected by the treatment of the drapery. ${ }^{10}$ The question arises, to which painter of the

9 I can recall only the following: (1) two gems in the Brit. Mus. (Cades, Abdrücke, Nos. $673,681)$; the style of both is that of the fifth century ; (2) a gem of severe style in Gerhard, Über den Gott Eros, pl. 1., 8. In each case Eros is a perfectly mature youth, but how far the type approximates to Hermes, the small scale of the design forbids me to say.

${ }^{20}$ I quote only examples from the British Museum : E 191, E 297, E 571, Eros with closed extended legs; E 13, E 187, E 293 (rev.), E 307, E 388, E 464, with bent knees; E 126, E 189, flying diagonally; E 293 (obv.), flying horizontally ; E 129, F 37, upper part of body bent backwards. Flight correctly rendered, with or without aid of drapery: E 231 (?), E 241, and among Italian vases, F 138, 184, $306,310,314,315,399,400,458$. Even on the Peleus-vase $\mathrm{E} 424$, which in many respects shows a remarkable advance on the latest fifth century vases, Eros still flies without inclining his head, or bending the hips outwards, or having drapery underneath him.

The flight of Nike had as a general rule the same development. We see her flying diagonally on $B 357$ and $E 584$; with bent-in knees, without aid of drapery, E 179, 287, 453, 469, 513. But on the vases of the fifth century she already appears in natural and easy flight, as on E 312 and E 406 ; cf. E 432, E 498 . This is 
fourth century the merit of this improvement must be ascribed, but it is impossible to give a definite answer. I should be most inclined to fix upon Pausias, the contemporary of Praxiteles. It was he who 'primus lacunaria pingere instituit, nec cameras ante eum taliter adornari mos fuit' (Pliny, H. N. xxxv. 123). According to the unanimous opinion of

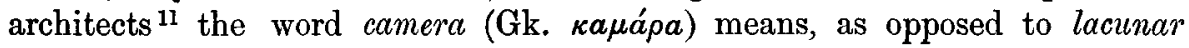
and fornix, a kind of arched roof. which in Greek times was made of wood. As none have been preserved, it is impossible to enter into the constructive details. So nuch however seems to be established by the evidence of antiquity, that between the longitudinal beams and the crosspieces were quadrangular spaces of varying size, which were closed in above with wooden tablets. Pausias then was the first to adopt the practice of painting these lacunaria (plural of lacunarium). His innovation did not however take the form of painting the same with ornaments or heads and busts, of both of which systems we have actual examples in the fifth century. ${ }^{12}$ His merit must rather consist in the fact that he first introduced the idea of painting in the lacunaria whole compositions of one or more figures. These wooden roof-panels which he painted are in my opinion absolutely identical in appearance with the still existing semicircular curved panels in the roof of the tepidarium of the smaller baths at Pompeii, in the Casa Farnesina at Rome, and elsewhere. Julius Lessing in his preface to the publication of the latter (Berlin, 1891, pls. 12-16) has very rightly remarked that this arrangement of rectangular partitions and clearlymarked-off panels must have been derived from wooden timber roofs.

The roof of the Pompeian tepidarium referred to (reproduced in Museo Borbonico, ii. 53) is our best possible authority for the manner in which flying, leaping, and swimming figures were lavished on the decoration of such lacunaria. In the six panels there illustrated we see five flying, and only one standing figure. Further the foreshortening necessitated by the vaulting (cf. Brunn, Künstlergesch. ii. p. 145) is rendered less objectionable by flying than by standing figures. I would suppose then that it was above

explained by the fact that her drapery was at an early period applied to this purpose of making her flight as easy as possible. The Nike of Paeonios is another example; she cannot however be compared with those above-mentioned, as she has one foot resting on the ground. i.e. the base, and consequently does not fly clear.

11 Cf. above all the Dictionary of Architecture issiced by the Architectural Publication Society, s.v. Camera and Lacunar (with reference to ancient authorities) ; also Weale-Hunt, Dict. of Terms used in Architecture, 4th edition, 1876; Durm, Baukunst der Römer, p. 283.

12 The former is proved from Helbig, Untersuch. uber d. campan. Wandmalerci, p. $132 a, 2$. A classical example of the latter is a lacunarium in the Brit. Mus. from the Nereid monument, on which a head is painted in full face. Six (J.H.S. xiii. p. 133) has adduced this in support of his view that this monument belongs to the first half of the fourth century, but his arguments are not convincing; and I am still persuaded that the monument dates from the fifth century. Moreover Six's inter. pretation of the B. M. astragalus vase is not to my mind satisfactory. Rather than Aurae and Aeolus we should regard the figures as nine personified astragali ( $\psi \hat{\eta} \phi o i)$, by means of which the figure on the left (much restored) declares oracles. Cf. a similar relief from Sagalassos in Lanckoronski's Städte Pamphiliens u. Pisidiens, figs. 109, 110, and for the astragalus oracle, Petersen ibid. 


\section{A FLYING EROS FROM THE SCHOOL OF PRAXITELES.}

all the painting of the lacunaria that suggested to Pausias the opportunity of entirely overcoming the old difficulty of the correct representation of flying male figures, as illustrated by the Eretrian terracotta, the Ganymede of Leochares, and other examples.

A merit of this kind would be naturally earned by one of the Sicyonian school of painting, and especially by one of Pausias' talents, who parvas. pingebat tabellas maxumeque pueros. ${ }^{13}$ The same artist painted an Eros in the

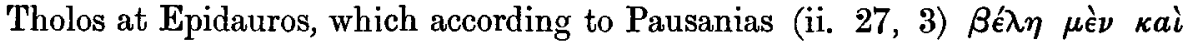

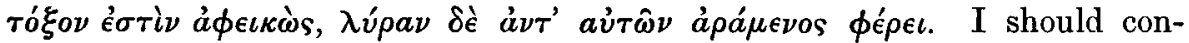
jecture that this Eros was represented flying downwards, in accordance with an old tradition, ${ }^{14}$ and in a similar attitude to the figure from Eretria which we have discussed.

P. BIENKOWSKI.

Krakow, Summer 1895.

13 I see no ground for rendering pucros 'children'; I take it as used in contradistinction to barbati.

14 On the vases of the fifth century a flying Eros frequently occurs, with the lyre held downwards in his left hand, a sash held up in his right, e.g. E 191 in Brit. Mus. Another Eros playing the lyre and flying downwards is seen on the lekythos published by Benndorf (v. supr.), and on E 126 in Brit. Mus. 


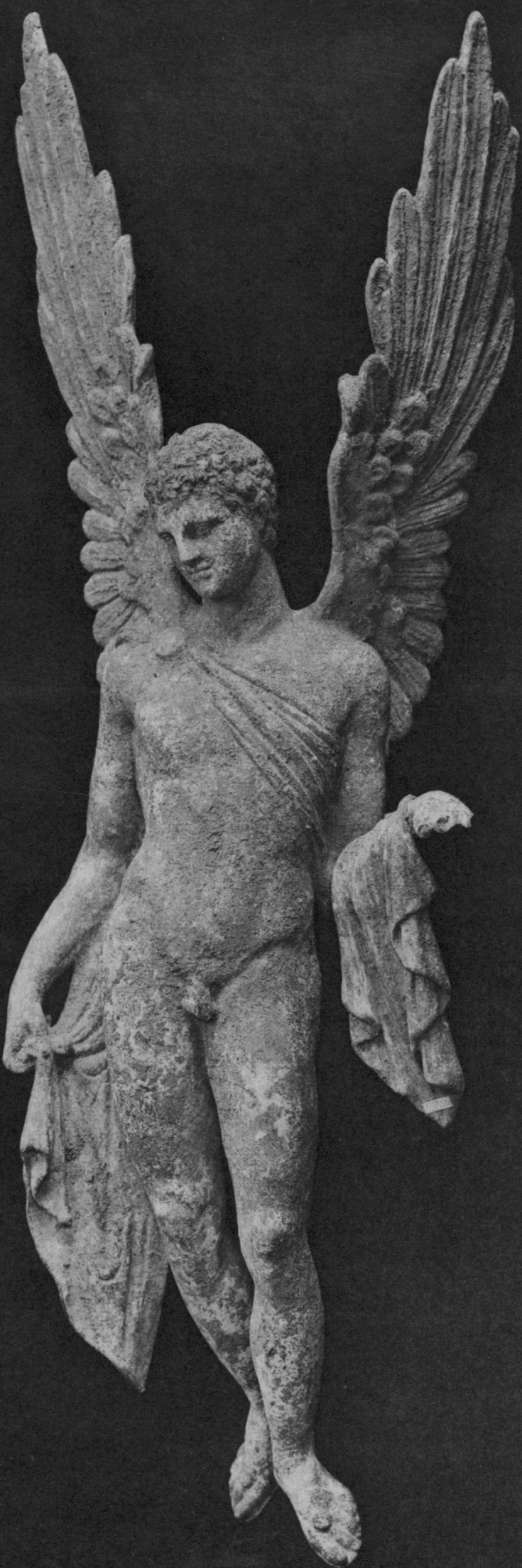

